\title{
Optimizing post-mining land use for pit area in open-pit mining using fuzzy decision making method
}

\author{
A. H. Bangian · M. Ataei $\cdot$ A. Sayadi • \\ A. Gholinejad
}

Received: 12 April 2011 / Revised: 27 October 2011/ Accepted: 19 November 2011/Published online: 9 May 2012

(c) CEERS, IAU 2012

\begin{abstract}
Open-pit mining method has severe environmental impacts which should be prevented, monitored, controlled, and reduced by mined-land reclamation process. After mine closure, a permanent post-mining land use should be implemented as an appropriate choice for using different sections of mined land. The most appropriate alternative of post-mining land use for each section of mined land is presented as the optimum post-mining land use. Pit area among different sections of mined land has more significant effects on the environment and also on defining the optimum post-mining land use for other sections of mined land. Though there are several alternatives and criteria for defining the optimum post-mining land use, the multi-attribute decision-making methods can be efficient techniques in this regard. The nature of the effective parameters used for defining the optimum post-mining land use is the same as Fuzzy numbers including incremental changes without definite limits. Thus, application of the Fuzzy multi-attribute decision-making modeling can produce more reliable results than that of other techniques. As well, pair-wise comparisons and judgments through Fuzzy numbers have proper consistency with the nature of the
\end{abstract}

A. H. Bangian $(\bowtie) \cdot$ A. Gholinejad

Department of Mining Engineering, South Tehran Branch, Islamic Azad University, Tehran, Iran

e-mail: ah_bangian@azad.ac.ir

M. Ataei

Department of Mining Engineering,

Shahrood University of Technology, Shahrood, Iran

A. Sayadi

Department of Mining Engineering, Tarbiat Modares University,

Tehran, Iran effective parameters; therefore, a model is developed to attain the optimum post-mining land use for pit area through Fuzzy analytical hierarchy processing. As a case study, the model was implemented in Sungun copper mine in the Northwest of Iran. Forestry-lumber production was defined as the optimum post-mining land use containing the greatest relative importance coefficient 3.019 for the pit area in this mine.

Keywords Environmental impacts - Fuzzy analytical hierarchy processing $\cdot$ Reclamation $\cdot$ Sustainable development

\section{Introduction}

Open pit mining is an efficient method for exploitation of a wide range of ore bodies especially for massive reserves of shallow metallic substances. In this mining method production planning (PP) is carried out based on the defined ultimate pit limit (UPL). On the other hand, UPL is defined based on block economic values (BEVs). Therefore, BEVs should be accurately calculated to attain an accurate UPL and consequently to plan an accurate PP in order to achieve maximum net present value (NPV) of a project. In Appendix, Table 11 presents a list of the acronyms used through the whole paper.

Block economic values is currently calculated on the basis of the return obtainable from any ore in the block, less the cost of mining and processing the block (Whittle 1988). The costs which are entered in BEV calculation consist of relevant direct costs of mining and processing of each block and any overhead expense which would stop if mining stopped (Whittle 1989, 1990). 
Nowadays closure and reclamation stage in a mining project is emphatically enforced by the relevant environmental protection regulations in many countries. For instance, FLPMA (1976) includes the act and policies forcing mining companies to rehabilitate mined land accurately, SMCRA (1977) details the act, guidelines and procedures to carry out mined-land reclamation accurately, BAOC (1977) includes the regulation relating to back to the original contour in mined-land restoration, BLM (1992) dictates several goals and standards for mined-land reclamation, AEPG (1995) includes three goals for reclamation planning, restoration, and replacing ecosystem, RCTSMR (2002) provides several directions for open-pit uranium and surface coal mines rehabilitation, NWT (2005) offers several directions and goals for reclamation planning, and AG (2007) includes several criteria for mined land reclamation etc. Therefore, this indicates that the direct and dependent variable overhead costs of closure and reclamation should be included in the calculation of BEV as it is necessary for other stages of open-pit mining.

Post-mining land use (PMLU) is the most effective indicator which defines the costs of closure and reclamation processes with respect to the specifications of a mine site. Therefore, identification of the optimum post-mining land use (OPMLU) among different applicable PMLUs is a key point to accurately determine closure and reclamation costs.

Prior to the late 1960s the issue of environmental protection had received little attention and the response of Governments to "localized" pollution problems was generally to enact weak regulatory legislation that was poorly enforced (United Nations 1993). In the after years, the environment protection debate has become more focused on the depletion and degradation of the natural resources, in particular, water, air, and non-renewable resources. The term sustainable development was devised to reflect this growing concern with the interaction among economic growth and long-term environmental quality. Sustainable development has been defined as "development that meets the needs of the present without comprising the ability of future generations to meet their own needs" (Bruntland 1987).

Based on the World attention to sustainable development, various international guidelines and standards were issued in order to protect the environment at mining sites and to sustain development through different conferences, committees, and organizations such as: A guide for revegetating coal mine soils (Vogel 1981), guidelines for reclaiming mine soils and overburden in the western United States (Barth et al. 1987), guidelines for Abandonment and Restoration Planning for Mines in the Northwest Territories (Northwest Territories Water Board 1990), UNEP/IEO (1991) which include "Environmental Aspects of Selected Non-ferrous Metals $(\mathrm{Cu}, \mathrm{Ni}, \mathrm{Pb}, \mathrm{Zn}, \mathrm{Au})$ Ore Mining", ICME (1991a, b) Environmental Policy, UNESCAP (1992) which include "Environmental Impact Assessment Guidelines for Mining Development", Guidelines for Cyanide Leaching Projects (CO/NRMLRD 1992), Technical Guide for the Environmental Management of Cyanide in Mining (Higgs 1992), UNRFNRE (1993) which include "Environmental Protection Guidelines", National Sustainable Development Strategy-Zambian Mining Sector Perspective (Limpitlaw 2001, 2003), Mining and the Environment-Berlin Guidelines (United Nations 1992, 1994) which include the need to translate the rhetoric of sustainable development into operational standards, guidelines of "Development, Environment and Mining" (World Bank 1994) which highlighted the trends in environment protection policies and social impact issues associated with mining, Rio Declaration principals and the Berlin Guidelines (United Nations Department of Public Information 1992) which include to guide the international community in achieving global sustainable development in mining sector, UNDDSMS (1994) which include the guidelines titled "Environmental Guidelines for Mining Operations", International Strategies for Implementing Sustainable Development (Boer 1994), Manual and standards for erosion and sediment control measures (ABAG 1995), guidelines for Hard Rock Mining: State Approaches to Environmental Protection (Mcefish 1996), practical guidelines and interpretation for Static-test methods most commonly used to predict acid-mine drainage (White et al. 1999; Rashidinejad et al. 2008), An Environmental Management guide for cyanide mining (Mudder and Botz 2001), Mine Reclamation Guidelines for the Northwest Territories and Nunavut (INAC 2002a, b), Mine Site Reclamation Policy for the Northwest Territories (INAC 2002a, b).

In the recent decades different mandatory environment protection regulations have also been issued by different countries in order to control and treat environmental impacts of mining activities. These regulations contain several views such as: to protect and to prevent propagation and also immigration of the generated pollutions by mining activities, to control and to prevent increase of the rate of generation of pollution, to treat the generated contamination, to identify the type and rate of contamination generation, etc. Also several regulations have been issued in order to restore, reclaim and rehabilitate mined-land area in the recent decades. These regulations define the different aspects to recognize applicable alternatives for PMLU and also the effective criteria and attributes for selecting the most prior alternative.

UNEP/IEO (1991) with regard to Mining and Environment Protection Legislation declared that countries with a mining sector will usually incorporate environment 
protection requirements, such as waste disposal, water quality controls, rehabilitation and occupational health and safety within their relevant mining laws.

The World Bank (1994) announced Government roles in Environment Protection are gradually evolving in response to changing perceptions of their involvement in mining operations themselves, and as experience with earlier control systems are re-evaluated. UNDDSMS (1994) issued a guide in with respect to importance of environmental impact assessment (EIA) of mining projects which included to ensure that environmental issues are addressed adequately and that any potential adverse environmental impacts are foreseen at the appropriate stage of project design. Environmental impact assessment process (Abaza 1993) should always be envisaged as an integral part of the planning process, which is initiated at the project level from commencement of the project's design. Environmental Quality Standards and Criteria (UNDDSMS 1994) which provide the numerical limits to which industrial operations must be designed and managed, have been issued by different organizations during the last couple of decades. Enforcement Mechanisms (UNDDSMS 1994) which include regulatory frameworks for protection of the environment from adverse effects of mining and mineral processing are increasing in number and complexity, have been arranged by many countries during the last two decades. Zambian National Legislative Framework (ICME 1991a, b) prior to 1990 included Natural Resources Conservation Act in 1970, Water Act in 1964, Forest Act in 1973, National Parks and Wildlife Act in 1968, Town and country Planning Act in 1962, Industrial Development Act in 1974, in the after years the Zambian Government has become increasingly concerned about the effect on the environment of mining and other industrial activities, and of the effect of a rapidly growing population on the use of land, water, and forest resources. This concern led to the Environmental Protection and Pollution Control Act No. 12 (EPPCA 1990) being formulated in 1990, and subsequently enacted in 1992.

According to the above-mentioned standards, guidelines, and regulations, it is deduced that selecting the applicable alternatives, effective criteria and attributes can be carried out based on the specific situation of a project. Therefore, to develop multi-attribute decision-making (MADM) modeling to attain OPMLU, the applicable alternatives and the effective criteria and attributes are judged by Experts and the group of consensus based on the relevant aspects through pair-wise comparisons.

In the literature on the subject during the last few decades, several researchers have presented different approaches to recognize OPMLU according to Table 1. Nevertheless, all of these approaches were developed for mined land in strip mining methods or in a general situation without any description of different sections of mined land in open-pit mining. Due to the fact that different sections of mined land in open-pit mining consist of pit(s), waste dump(s), tailing pond(s), roads, areas for on site facilities, and free land zones which are not mined have different specifications, none of the previous approaches have specifically recognized OPMLU for a definite section of mined land. Also the approaches presented through creating MADM structures, have not been considered based on the fuzzy quality of the effective parameters. These approaches have limitedly presented the alternatives and the effective criteria for recognizing the OPMLU.

AHP method facilitates judgments and calculation preferences using pair-wise comparisons. It also is the best procedure to carry out pair-wise judgment comparisons (Saaty 1977). Nonetheless, human judgments are commonly imprecise hence the priorities are not determined by precise numeric amount (Herrera and Herrera 2000). Fuzzy theory was developed by Zadeh (1965) to overcome imprecise judgments and preferences. Many of the weighing methods of attributes and alternatives are intellectually carried out by qualitative scales, whereas logical determination of the priorities is difficult for decision makers in general (Warren 2004). Therefore, in order to carry out precise pair-wise judgment comparisons and decision making, Fuzzy sets theory and AHP method were combined by Buckley (1985). Afterwards other methods were presented through combining these two approaches (Cheng 1996). Since fuzziness and vagueness are common characteristics in many decision-making problems, a fuzzy analytical hierarchy processing (FAHP) method should be able to tolerate vagueness or ambiguity (Mikhailov and Tsvetinov 2004).

In other words, FAHP is capable of capturing a human's appraisal of ambiguity when complex multi-attribute decision-making problems are considered (Erensal et al. 2006). Accordingly, FAHP was applied in many sciences through different applications (Buyukozkan et al. 2004; Cheng and Tang 2009; Huang and Wu 2005; Naghadehi et al. 2009; Safari et al. 2010). Fuzzy sets theory provides a wider frame than classic sets theory. It has been contributing to capability of reflecting real world (Ertugrul and Karakasoglu 2009). Fuzzy sets and logic are powerful mathematical tools for modeling. Their role is significant when applied to complex phenomena not easily described by traditional mathematical methods, especially when the goal is to find a good approximate solution (Bojadziev and Bojadziev 1998).

The major difference among defining OPMLU in strip mining methods and open-pit mining is due to the difference among their reclamation procedures. Continuous reclamation at the end of each cycle of strip mining methods is opposite to permanent reclamation after mine 
Table 1 A brief literature on the approaches to define PMLU during the last few decades

\begin{tabular}{|c|c|c|}
\hline Author (year) & Approach & Advantages \\
\hline Cairns (1972) & $\begin{array}{l}\text { Using ecological considerations to recognize the most suitable } \\
\text { reclamation procedure and PMLU }\end{array}$ & $\begin{array}{l}\text { Presenting ecological criteria to classify mined-land } \\
\text { uses }\end{array}$ \\
\hline $\begin{array}{l}\text { Bandopadhyay and } \\
\text { Chattopadhyay } \\
\text { (1986) }\end{array}$ & Using a Fuzzy algorithm to select PMLU & $\begin{array}{l}\text { Presenting an Fuzzy algorithm based on the previous } \\
\text { experimental considerations }\end{array}$ \\
\hline Alexander (1998) & $\begin{array}{l}\text { Using the effectiveness of small-scale irrigated agriculture in } \\
\text { the reclamation of mine land soils }\end{array}$ & $\begin{array}{l}\text { Presenting different procedures to successfully apply } \\
\text { small-scale irrigated agriculture as PMLU }\end{array}$ \\
\hline Chen et al. (1999) & $\begin{array}{l}\text { Using a limiting factor for defining restoration procedure of } \\
\text { soil fertility in a newly reclaimed coal mined site in Xuzhou }\end{array}$ & $\begin{array}{l}\text { Presenting some criteria to define reclamation } \\
\text { procedure for a specific case of coal mined land }\end{array}$ \\
\hline Joerin et al. (2001) & $\begin{array}{l}\text { Using GIS and outranking multi criteria analysis for assessing } \\
\text { suitability of PMLU }\end{array}$ & $\begin{array}{l}\text { Presenting a multi criteria structure to outrank } \\
\text { suitability of PMLU by using GIS }\end{array}$ \\
\hline Mchaina (2001) & $\begin{array}{l}\text { Using environmental planning considerations for the } \\
\text { decommissioning, closure and reclamation of mined land }\end{array}$ & $\begin{array}{l}\text { Presenting environmental considerations to select } \\
\text { suitable PMLU }\end{array}$ \\
\hline $\begin{array}{l}\text { Uberman and Ostrêga } \\
\text { (2005) }\end{array}$ & $\begin{array}{l}\text { Using Analytical Hierarchy Processing (AHP) in the } \\
\text { revitalization of post-mining regions }\end{array}$ & $\begin{array}{l}\text { Presenting an analytical hierarchy process to select } \\
\text { PMLU }\end{array}$ \\
\hline Osanloo et al. (2006) & $\begin{array}{l}\text { Using AHP to select PMLU through consideration of the } \\
\text { primary and secondary factors }\end{array}$ & $\begin{array}{l}\text { Presenting an AHP structure to select PMLU by } \\
\text { introducing and considering the primary and } \\
\text { secondary factors }\end{array}$ \\
\hline $\mathrm{Mu}(2006)$ & Using developing a suitability index for residential land use & $\begin{array}{l}\text { Presenting suitability indexes to implement } \\
\text { residential land use }\end{array}$ \\
\hline Bascetin (2007) & $\begin{array}{l}\text { Using AHP to create a decision support system to define the } \\
\text { PMLU }\end{array}$ & Presenting an AHP structure to recognize PMLU \\
\hline Cao (2007) & $\begin{array}{l}\text { Using to regulate mined-land reclamation in developing } \\
\text { countries: the case of China }\end{array}$ & $\begin{array}{l}\text { Presenting a classification for issued regulations to } \\
\text { analyze suitability of PMLUs }\end{array}$ \\
\hline $\begin{array}{l}\text { Soltanmohammadi } \\
\text { et al. }(2008 \mathrm{a}, \mathrm{b} \text {, } \\
\text { 2009a, b) }\end{array}$ & $\begin{array}{l}\text { Using multi criteria decision-making methods to rank } \\
\text { suitability of PMLUs }\end{array}$ & $\begin{array}{l}\text { Presenting a MCDM structure to outrank suitability } \\
\text { of PMLU, developing effective criteria }\end{array}$ \\
\hline
\end{tabular}

closure in open-pit mining. Therefore, two major factors: (1) the specifications of each section of mined land and, (2) the desired objectives of the reclamation program after mine closure, are involved in defining OPMLU.

The approach of this paper is developed on the basis of two innovative ideas. The first is to create a model based on the variation among different sections of mined land, and to develop effective criteria to define OPMLU for each section of mined land. The second is due to the fuzzy nature of the effective parameters for defining OPMLU which is same as Fuzzy sets and numbers.

Fuzzy sets use a spectrum of numbers instead of using absolute numbers, and Fuzzy numbers include incremental changes without definite limits. Thus, the approach is developed by the use of Fuzzy MADM modeling for each section of mined land in open-pit mining. As the pair-wise comparisons and judgments through Fuzzy numbers have a high rate of consistency with the nature of the effective parameters for defining OPMLU, FAHP can produce more reliable results than the other techniques.

Pit area due to its shape and depth, affects the adjacent environment as well as effecting the selection of the OPMLU of the other sections of mined land. Therefore, pit area among different sections of mined land is the main focus of this paper. Defining OPMLU for other mined land sections will be focused in another paper. This approach is developed through a model based on the application of FAHP to recognize OPMLU for pit area with 17 applicable PMLU alternatives, five relevant effective criteria, 96 attributes, and sub-attributes. Sungun copper mine was considered by the developed model as a case study. The steps of implementation of the model are presented through the case study to define OPMLU for the pit area of Sungun copper mine.

\section{Relevant alternatives and criteria to define OPMLU for pit area}

An open-pit mine covers a large area of mined land consists of different sections as the above. Among these sections, pits are mostly the deepest area where pollutants generated through mining activities come into contact with surface and underground waters. Pit area mostly covers a more extended region than the other sections of mined land. The most severe effect of open-pit mining on landscape quality is created by pit excavation. Thus, it is 
Table 2 Alternatives of applicable types of PMLU for pit area in open-pit mining

\begin{tabular}{|c|c|c|c|c|}
\hline No. & Overall PMLU & No. & Detailed PMLU & Alternative \\
\hline \multirow[t]{4}{*}{1} & \multirow[t]{4}{*}{ Agriculture } & 1 & Arable farmland & $\mathrm{A}-\mathrm{AF}$ \\
\hline & & 2 & Garden & A-G \\
\hline & & 3 & Pasture & A-P \\
\hline & & 4 & Nursery & A-N \\
\hline \multirow[t]{3}{*}{2} & \multirow[t]{3}{*}{ Forestry } & 5 & Lumber production & F-LP \\
\hline & & 6 & Woodland & $\mathrm{F}-\mathrm{W}$ \\
\hline & & 7 & Shrubs and native forestation & F-SNF \\
\hline \multirow[t]{3}{*}{3} & \multirow[t]{3}{*}{ Lake } & 8 & Lagoon & L-L \\
\hline & & 9 & Aquaculture & L-A \\
\hline & & 10 & Aquatic sports & L-AS \\
\hline \multirow[t]{3}{*}{4} & \multirow[t]{3}{*}{ Pit backfilling } & 11 & Water reservoir & PB-WR \\
\hline & & 12 & Garbage burying & PB-GB \\
\hline & & 13 & Landfill & PB-L \\
\hline \multirow[t]{4}{*}{5} & \multirow[t]{4}{*}{ Miscellaneous } & 14 & Park & M-P \\
\hline & & 15 & Blasting techniques training & M-BTT \\
\hline & & 16 & Ski and rock artificial climbing & M-SRAC \\
\hline & & 17 & Military activities training & M-MAT \\
\hline
\end{tabular}

In this paper, the effective criteria to define OPMLU for pit area are presented more extensively than the previous approaches including five overall categories, 96 attributes, and sub-attributes. Fig. 1 shows the hierarchy of the developed MADM model. This hierarchy comprises five main columns consisting of the criteria description, the abbreviations of the attributes and sub-attributes. Description of the mentioned abbreviations is presented in the next paragraphs.

Economical criterion is the first category which includes several attributes as follows: break even point (BEP), income (Incom.) which includes three sub-attributes: mining project income (MPI), increase in income of local community (IIL), and increase in governmental incomes (IGI), internal rate of return (IRR), regional economical condition coordination (RECC), positive changes in real estate value (PCRE), cost (Cost) which includes three subattributes: operational costs (OPC), capital costs (CAC), and maintenance and monitoring costs (MMC) and potential of investment absorption (PIA).

Executive criterion also includes several attributes as follows: authority of reclamation project execution (ARPE), executive managing experiences availability (EMEA), reclamation technique availability (RTA), required machines and equipments availability (RMEA), Need to specialist workforces (NSW), budget providing potential (BPP), and regional potential for implementation the new land use (RPI).

Social criterion includes several attributes as following: cultural (Cult.) included six sub-attributes: regional common economical activities (RCEA), regional social activities (RSA), regional morals customs (RMC), regional in two groups of
several attributes. 


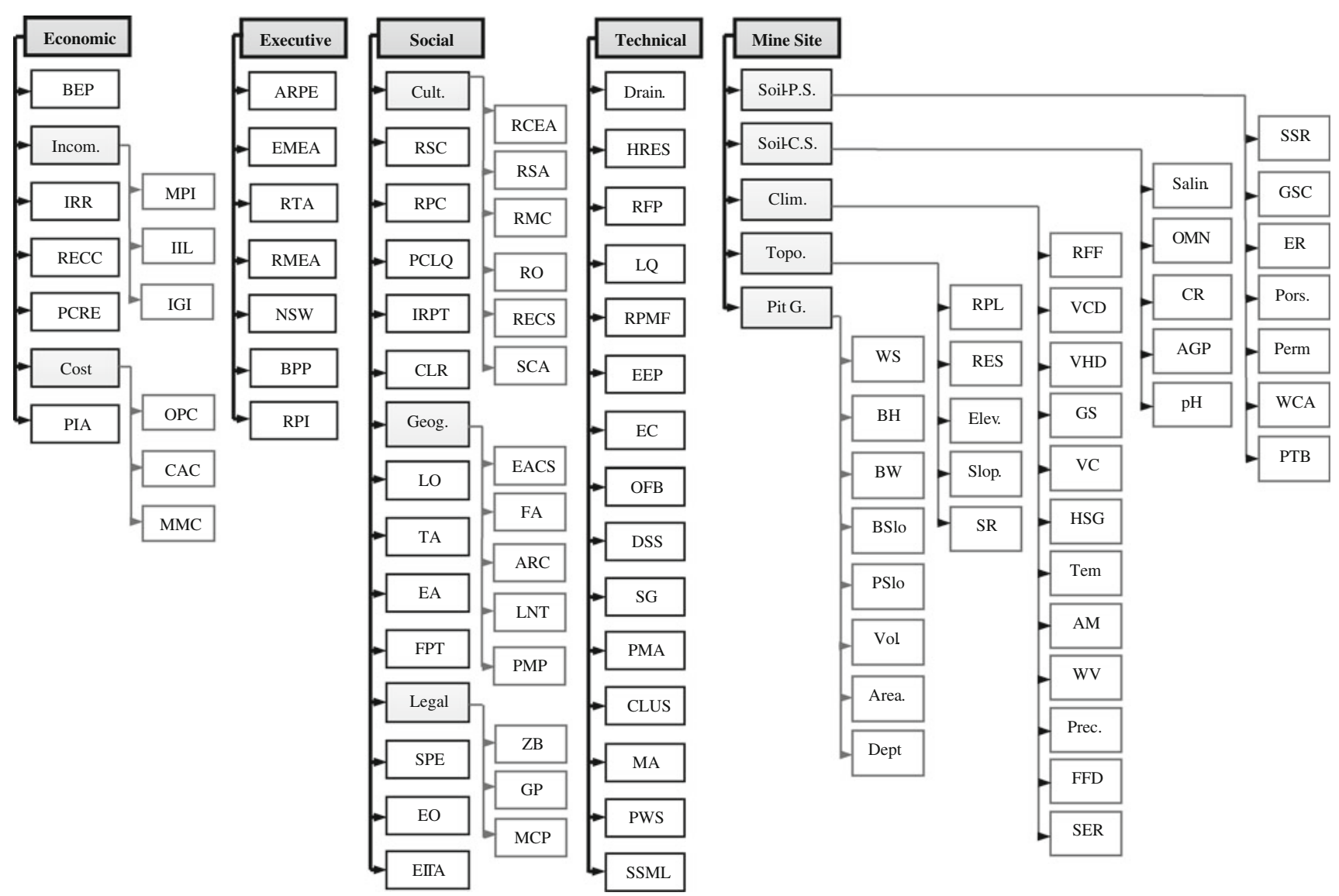

Fig. 1 The hierarchy of the developed MADM model comprises the criteria, attributes and sub-attributes to define OPMLU for pit area in openpit mining

opponents (RO), regional ethnic customs specifications (RECS) and social and cultural condition of adjacent areas (SCA), regional safety condition (RSC), regional political condition (RPC), positive changes in livelihood quality (PCLQ), increase in regional public skills and technical knowledge (IRPT), consistency with local requirements (CLR), geographical (Geog.) included five sub-attributes: easy accessibility in cold seasons (EACS), facilities accessibility (FA), accessibility or road condition (ARC), location towards nearest town (LNT) and proximity of mine site to population centers (PMP), land ownership (LO), tourism attractions (TA), ecological acceptability (EA), frequency of passing through mine site (FPT), legal (Legal) included three sub-attributes: zoning by-laws (ZB), government policy (GP) and mining company policy (MCP), serving the public education (SPE), employment opportunity (EO) and effects on immigration to the area (EITA).

Technical criterion includes several attributes as follows: drainage (Drain.), high-rate earthquake statistics (HRES), regional flood potential (RFP), landscape quality (LQ), reusing potential of mine facilities (RPMF), extreme events potential (EEP), environmental contaminations (EC), outlook of future businesses (OFB), distance from special services (DSS), structural geology (SG), prosperity in the mine area (PMA), current land use in surrounding area (CLUS), market availability (MA), proximity to water supply (PWS), and shape and size of mined land (SSML).

Mine site criterion comprises the following five attributes: Soil physical specifications, Soil chemical specifications, climate, topography and pit geometry which consist of several sub-attributes.

Soil physical specifications (Soil-P.S.) attribute consists of the sub-attributes, such as, soil stability rate (SSR), general soil color (GSC), erosion rate (ER), porosity (Pors.), permeability (Perm.), water conduction ability (WCA) and, petrologic type of bedrock (PTB).

Soil chemical specifications (Soil-C.S.) attribute consists of the sub-attributes, such as, salinity rate (Salin.), organic material and nutrient elements (OMNE), contamination rate (CR), acid generation potential (AGP), and $\mathrm{pH}$ $(\mathrm{pH})$.

Climate (Clim.) consists of several sub-attributes: regional flora and fauna (RFF), very cold days (VCD), very 
hot days (VHD), geographical situation (GS), vegetative coverage (VC), hydrology of surface and groundwater (HSG), regional average temperature (Temp.), air moisture (AM), wind velocity (WV), precipitation (Prec.), frost-free days (FFD), and surface evaporation rate (SER).

Topography (Topo.) comprises several attributes as follows: regional pezometeric level (RPL), regional exposure to sunrise (RES), overall regional elevation (Elev.), overall regional slope (Slop.) and surface relief (SR).

Pit geometry (Pit G.) consists of the several following sub-attributes: wall stability (WS), benches height (BH), benches width (BW), benches slope (BSlop.), pit slope (PSlop.), pit volume (Vol.), pit area (Area.) and pit depth (Depth.).

According to Fig. 1, the procedure includes 1 pair-wise comparison matrix $96 \times 96$ of the attributes and 96 pairwise comparison matrixes $17 \times 17$ of the alternatives with regard to each attribute. In this approach extensive attributes and sub-attributes of the model result clearer and more reliable definition of the optimum choice of PMLU for pit area than the previous approaches. The first reason for considering more attributes in this approach is to consider some new applicable PMLUs for pit area. The second is that of, differences among inherent specifications of different sections of mined land in open-pit mining. Furthermore, it is obvious that some types of PMLU are very rarely homogeneous relating to some of the effective parameters on their implementation. Therefore, five main criteria in this approach have been considered in order to cover the most effective parameters in implementing different types of PMLU. Ninety-six attributes are the direct and also detailed effective parameters which demonstrate complete preferences in ranking of the alternatives of PMLU for pit area. Also they cover some overall effective parameters. For e.g., morphology and lithology are two overall parameters which are covered by the different attributes of mine site criterion as topography attribute and its sub-attributes, pit geometry attribute and its sub-attributes, soil attribute, and its physical and chemical subattributes.

\section{Use of FAHP to define OPMLU for pit area}

In this paper using FAHP which is one of Fuzzy MADMs, OPMLU for pit area is worked out. First, using AHP, pairwise judgment comparison matrixes are formed. Then through taking pair-wise judgment comparison matrixes to Fuzzy mode the data for FAHP is entered. Consequently, relative importance coefficients of the alternatives are obtained by the above procedure and then their priorities are determined. Finally the alternative with the highest priority is introduced as the OPMLU.
Analysis by Fuzzy analytical hierarchy processing method

With reference to Fuzzy thought, analysis of the structure of the model to attain OPMLU is carried out using FAHP. Fuzzy pair-wise comparison matrix is the entering data to FAHP algorithm. To produce the Fuzzy pair-wise comparison matrix, the pair-wise comparison matrix is made according to AHP algorithm. In this algorithm, firstly the hierarchy tree is established and then decision-making matrix is generated based on Saaty (1990) nine-point scale.

At the next step, pair-wise comparisons are executed amongst the members of the decision making matrix. Pairwise comparisons are carried out to determine relative preferences of attributes with reference to each other. The structure of a pair-wise comparison matrix for comparison amongst attributes is as shown in Eq. (1).

$$
\begin{aligned}
A= & {\left[\begin{array}{cccc}
a_{11} & a_{12} & \cdots & a_{1 n} \\
a_{21} & a_{22} & \cdots & a_{2 n} \\
\vdots & \vdots & \vdots & \vdots \\
a_{n 1} & a_{n 2} & \cdots & a_{n n}
\end{array}\right], } \\
& a_{i j}=1 / a_{j i}, a_{i i}=1, i, j=1,2, \ldots, n
\end{aligned}
$$

where $a_{i j}$ is the preference of element $i$ to element $j$ and vice versa for $a_{j i} ; i, j$ vary at natural numbers set. Saaty showed that the largest eigenvalue $\lambda$, of a reciprocal matrix $A$ is always greater than or equal to $\mathrm{n}$ (Saaty 1980). If pair-wise comparisons do not contain any inconsistencies, so $\lambda$ equals $n$. Comparisons comprise of more consistent judgments, have closer values of $\lambda$ to $n$. Consistency Index $(C I)$ measures the inconsistencies of pair-wise comparisons according to Eq. (2)

$C I=\left(\lambda_{\max }-n\right) /(n-1)$

where, $\lambda$ is an eigenvalue of matrix A. A consistency ratio (CR) is calculated by Eq. (3)

$\mathrm{CR}=100(\mathrm{CI} / \mathrm{RI})$

where, $\mathrm{CR}$ is consistency ratio, $\mathrm{CI}$ is consistency index, $\mathrm{RI}$ is random index and $n$ is number of columns. If $C I / R I<0.10$, then the degree of consistency is satisfactory. If $C I / R I>0.10$, then the degree of consistency is not satisfactory consequently the AHP comparisons may not have reliable results (Liang 2003). If CI and CR are satisfactory, then the preferences are calculated based on normalized values; otherwise the procedure is repeated until the results will be lain in the desired range.

Also if two or more decision makers are involved in measuring the priorities of alternatives and/or attributes, grouped AHP is applied (Altuzarra et al. 2004). In grouped AHP numeral average is calculated for different preferences of the experts as $x_{i j}^{\prime}$ in Eq. (4) 
$x_{i j}^{\prime}=\left(\prod_{l=1}^{k} x_{i j l}\right)^{\frac{1}{k}} ; i, j=1,2, \ldots, n ; i \neq j ; l=1,2, \ldots, k$

where, $l$ is the index of each decision maker, $k$ is the total number of all decision makers, $i, j$ are the indexes of the alternative and the attribute which are compared to each other. The important point in this regard is to prevent creating a high inconsistency ratio. Therefore, the issued preferences from the decision makers have to be relatively consistent with each other.

\section{Steps of FAHP algorithm}

First step comprises creating of Fuzzy pair-wise comparison matrix. In this step pair-wise comparison matrixes are established through Fuzzy thought and FTN using AHP method.

Second step consists of calculation the amount of $S_{k}$. In this step, $S_{k}$ amount which is a TFN and is calculated for each row of pair-wise comparison matrix according to Eq. (5).

$$
\begin{gathered}
S_{k}=\sum_{j=1}^{n} M_{k l} \times\left[\sum_{i=1}^{m} \sum_{j=1}^{n} M_{i j}\right]^{-1} ; i=1,2, \ldots, m ; \\
j=1,2, \ldots, n
\end{gathered}
$$

where $k$ is the number of each row, $i, j$ are the indexes of the alternative and attribute respectively.

Third step contains computation of the degree of possibility. In this step, degree of possibility of different $S_{k}$ is calculated. If $M_{i}$ and $M_{j}$ are two FTNs, degree of possibility of $M_{i}$ to $M_{j}$ is shown according to Eq. (6)

$$
\begin{aligned}
& V\left(M_{i} \geq M_{j}\right) \\
& =\left\{\begin{array}{l}
1, m_{i} \geq m_{j} \\
\frac{u_{i}-l_{j}}{\left(u_{i}-l_{j}\right)+\left(m_{j}-m_{i}\right)}, \quad l_{j} \leq u_{i}, i, j=1,2, \ldots, n ; j \neq i \\
0, \quad \text { otherwise }
\end{array}\right.
\end{aligned}
$$

where, $M_{i}=\left(l_{i}, m_{i}, n_{i}\right), M_{j}=\left(l_{j}, m_{j}, n_{j}\right)$ and $V\left(M_{i} \geq M_{j}\right)$ is degree of possibility of $M_{i}$ to $M_{j}$. Figure 2 illustrates the degree of possibility.

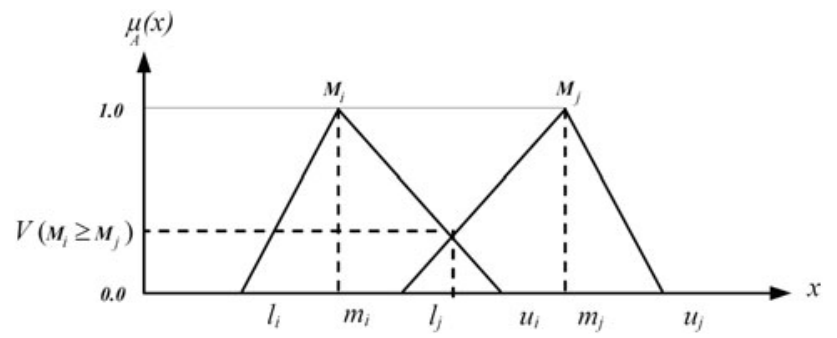

Fig. 2 The degree of possibility of $V\left(M_{i} \geq M_{j}\right)$
Degree of possibility of a FTN from another $k$ FTNs is calculated according to Eq. (7)

$V\left(M_{1} \geq M_{2}, \ldots, M_{k}\right)=\left[V\left(M_{1} \geq M_{2}\right), \ldots, V\left(M_{1} \geq M_{k}\right)\right]$

where, $k$ is the index of the last FTN.

Forth step includes calculation of the weights. Weights are calculated as shown in Eq. (8)

$$
\begin{aligned}
W^{\prime}\left(x_{i}\right)= & \operatorname{Min}\left\{V\left(S_{i} \geq S_{k}\right)\right\} ; i=1,2, \ldots, k ; k=1,2, \ldots, n ; \\
& k \neq i
\end{aligned}
$$

where, $W^{\prime}\left(x_{i}\right)$ is the desired weight. The vector of the weight is achieved according to Eq. (9)

$$
W^{\prime}=\left[W^{\prime}\left(c_{1}\right), W^{\prime}\left(c_{2}\right), \ldots, W^{\prime}\left(c_{n}\right)\right]^{T}
$$

where, $W^{\prime}$ is the vector of the weight of the attributes.

Fifth step is comprised of to obtain the vector of the weight of normalized attributes. The vector of the weight of normalized attributes is made when Eq. (10) is applied

$w_{i}=w_{i}^{\prime} / \sum_{j=1}^{n} w_{j}^{\prime}, \quad i, j=1,2, \ldots, n$

where, $i$ is the index of each attribute and $n$ is the number of all attributes.

Sixth step contains calculation of the relative importance coefficients of the alternatives and ranking of those. At six and the last step relative importance coefficients is produced using to multiply the weights of the attributes by achieved weights of the alternatives with respect to each attribute. In this step it is concluded that an alternative which has a greater relative importance coefficient, is more appropriate for implementing in the pit area. Figure 3 shows the steps comprising the FAHP procedure.

Implementation of the model in Sungun copper mine

As a case study the model was implemented in Sungun copper mine in northwest of Iran. The mineable ore reserve of the mine is about $380 \mathrm{Mt}$. Average grade of the deposit is $0.67 \%$ and overall stripping ratio (OSR) is 1.63. The estimation of mined land of Sungun copper mine is about 38 sq. $\mathrm{km}$ which will complete until the end of mining activities. There is the highest and the lowest elevation respecting free seas equal 2,460 and $1,700 \mathrm{~m}$. For that reason there are big differences in the height of different point of mined-land area (about $750 \mathrm{~m}$ ) and topography. Sungun is an open-pit mine with mountain climate. Temperature is cold till moderate with moderately humid condition. There are various flora and fairly compact natural vegetation (Rashidinejad 2004a, b).

Firstly pair-wise comparison matrix for selection of the PMLUs of the pit area was made using AHP method. The 


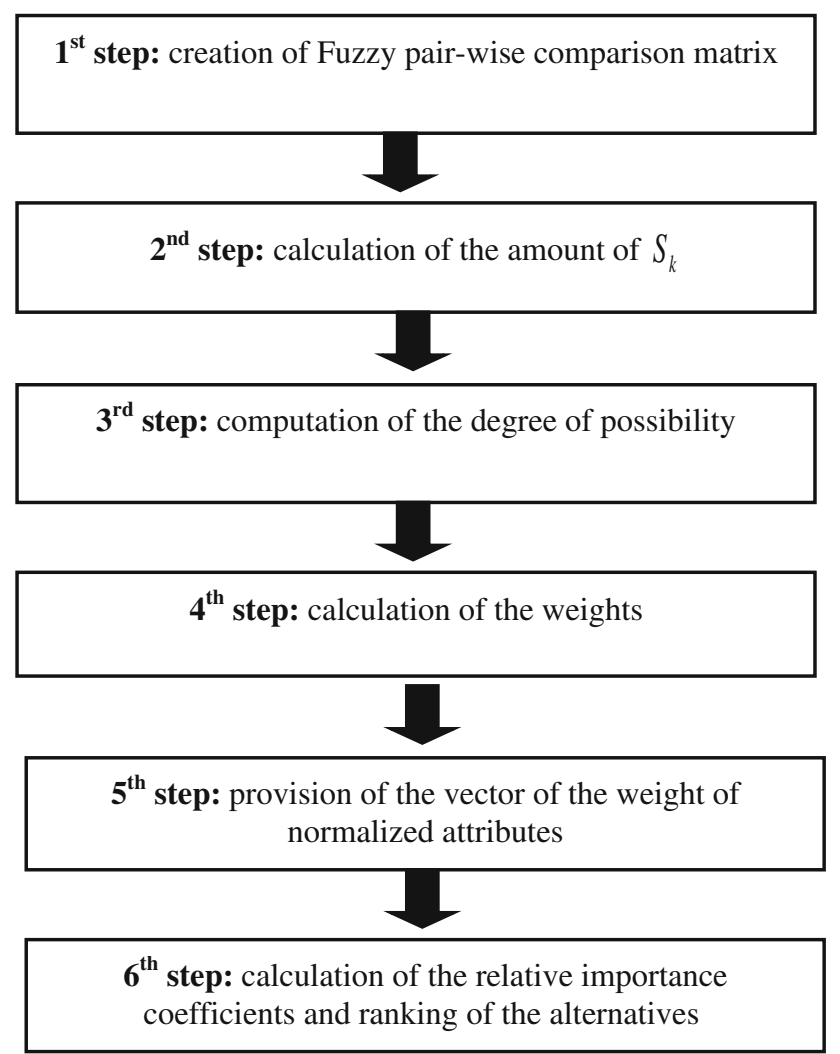

Fig. 3 The steps comprising the FAHP procedure

entry is then prepared for FAHP algorithm through changing the pair-wise comparison matrix to Fuzzy condition. Fuzzy pair-wise comparison matrix to select PMLUs of the pit area with respect to MPI attribute is shown in Table 3.

Calculations of FAHP algorithm including 17 alternatives and 96 attributes include enormous mathematical operations therefore it needs to be carried out use of a computer program. For this reason a program of more than 1,000 lines of code was written by a skilled programming team using $\mathrm{C}++$ language. The written program was called FAHP Selector. Hence to use FAHP Selector the pair-wise comparison scores are entered into the program as the inputs of the model. Consequently FAHP Selector program provides the preferences of the PMLU alternatives based on the entered scores.

In this step $S_{k}$ amount for each row of a pair-wise comparison matrix is calculated. To calculate $S_{k}$, the TFNs of each row firstly are added with each other then the achieved result is multiplied to the invert amount of the sum of all TFNs of the matrix, final result of this step is also a TFN. Calculation of weights of the alternatives is presented in Tables 4, 5 with respect to MPI attribute.

Consequently all TFNs of the alternatives are added to each other based on each row from Table 3 and the result is

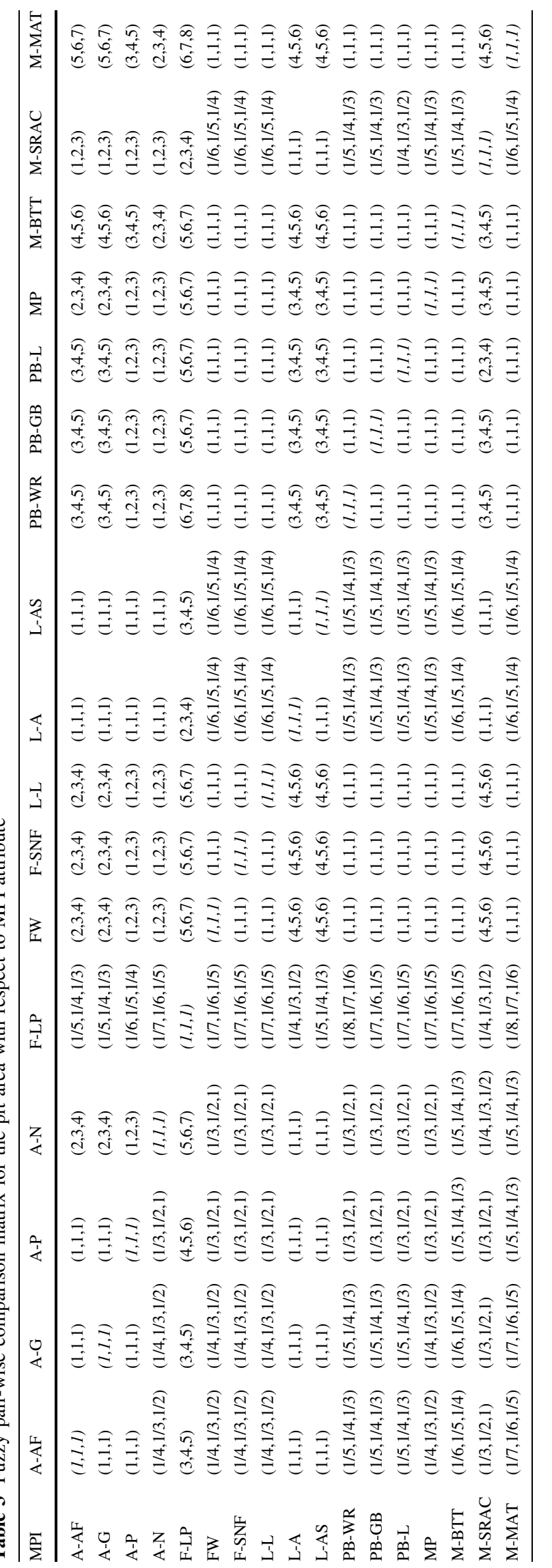


Table 4 Sum of the TFNs of each row of the Fuzzy pair-wise comparison matrix with regards to MPI attribute to obtain the $S_{k}$

\begin{tabular}{ll}
\hline Row no. & $\sum_{j=1}^{n} M_{k l}$ \\
\hline 1 & $(34.2,45.25,56.33)$ \\
2 & $(34.2,45.25,56.33)$ \\
3 & $(20.167,31.25,42.2)$ \\
4 & $(15.973,26.327,37.2)$ \\
5 & $(70.00,86.00,102.00)$ \\
6 & $(10.86,11.427,12.95)$ \\
7 & $(10.804,11.427,12.95)$ \\
8 & $(10.804,11.427,12.95)$ \\
9 & $(39.25,48.33,57.50)$ \\
10 & $(39.20,48.25,57.33)$ \\
11 & $(10.785,11.393,12.817)$ \\
12 & $(10.803,11.417,12.85)$ \\
13 & $(10.853,11.497,12.72)$ \\
14 & $(10.903,11.577,13.19)$ \\
15 & $(10.411,10.717,11.19)$ \\
16 & $(34.49,44.16,55.00)$ \\
17 & $(10.312,10.577,10.977)$ \\
$\sum_{i=1}^{m} \sum_{j=1}^{n} M_{i j}$ & $(384.015,476.276,576.484)$ \\
{$\left[\sum_{i=1}^{m} \sum_{j=1}^{n} M_{i j}\right]^{-1}$} & $(0.0017,0.0021,0.0026)$ \\
\hline
\end{tabular}

obtained as a TFN. Finally by multiplying inverted TFNs from Table 4, $\left[\sum_{i=1}^{m} \sum_{j=1}^{n} M_{i j}\right]^{-1}$ to each obtained Fuzzy from each alternative $\sum_{j=1}^{n} M_{k l}$, the amount of $S_{k}$ for each alternative is calculated. The amounts of $S_{k} \mathrm{~s}$ are presented as shown in Table 5.

In the next step as the third step, degrees of possibility of the $S_{k}$ s are calculated with respect to each other. Table 6 shows the achieved amounts of $S_{k}$ s using Eq. (6).

After that as the fourth step, degree of possibility for each $S_{k}$ is calculated by Eq. (7). The achieved degrees of possibility are as the scaled weights of each alternative with regard to MPI attribute. In the next step as the fifth step, weights and normalized weights of the alternatives with regard to MPI attribute are calculated using Eqs. (8), (10). The achieved normalized weights in this step are shown in Table 7.

The weights of the alternatives with regard to each attribute and also the weights of the attributes with regard to each other are achieved by the end of FAHP calculation. Lastly, to obtain relative importance coefficient for each alternative, normalized weights of the attributes are calculated. Then the weights of each alternative are defined with respect to the different attributes. By the abovementioned algorithm normalized weights of attributes and alternatives for the pit area are achieved. Some of these weights are as shown in Table 8 .

Finally, relative importance coefficients of the alternatives are calculated by multiplication of the weights of the attributes by achieved weights from the alternatives as shown in Table 9.

With reference to Table 9, it is concluded that lumber production has the highest rate of the relative importance coefficient among the different alternatives. It therefore is
Table 5 The achieved TFNs of $S_{k}$ s for each row with respect to MPI attribute

\begin{tabular}{lll}
\hline $\begin{array}{l}\text { Row } \\
\text { no. }\end{array}$ & $\sum_{j=1}^{n} M_{k l} \times\left[\sum_{i=1}^{m} \sum_{j=1}^{n} M_{i j}\right]^{-1}$ & $S_{k}$ \\
\hline 1 & $(34.20,45.25,56.33) \times(0.0017,0.0021,0.0026)$ & $(0.058,0.095,0.146)$ \\
2 & $(34.20,45.25,56.33) \times(0.0017,0.0021,0.0026)$ & $(0.058,0.095,0.146)$ \\
3 & $(20.167,31.25,42.20) \times(0.0017,0.0021,0.0026)$ & $(0.034,0.066,0.110)$ \\
4 & $(15.973,26.327,37.20) \times(0.0017,0.0021,0.0026)$ & $(0.027,0.055,0.097)$ \\
5 & $(70.00,86.00,102.00) \times(0.0017,0.0021,0.0026)$ & $(0.119,0.181,0.265)$ \\
6 & $(10.86,11.427,12.95) \times(0.0017,0.0021,0.0026)$ & $(0.018,0.024,0.034)$ \\
7 & $(10.804,11.427,12.95) \times(0.0017,0.0021,0.0026)$ & $(0.018,0.024,0.034)$ \\
8 & $(10.804,11.427,12.95) \times(0.0017,0.0021,0.0026)$ & $(0.018,0.024,0.034)$ \\
9 & $(39.25,48.33,57.50) \times(0.0017,0.0021,0.0026)$ & $(0.067,0.102,0.149)$ \\
10 & $(39.20,48.25,57.33) \times(0.0017,0.0021,0.0026)$ & $(0.067,0.102,0.149)$ \\
11 & $(10.785,11.393,12.817) \times(0.0017,0.0021,0.0026)$ & $(0.018,0.024,0.033)$ \\
12 & $(10.803,11.417,12.85) \times(0.0017,0.0021,0.0026)$ & $(0.018,0.024,0.033)$ \\
13 & $(10.853,11.497,12.72) \times(0.0017,0.0021,0.0026)$ & $(0.018,0.024,0.033)$ \\
14 & $(10.903,11.577,13.19) \times(0.0017,0.0021,0.0026)$ & $(0.018,0.024,0.034)$ \\
15 & $(10.411,10.717,11.19) \times(0.0017,0.0021,0.0026)$ & $(0.018,0.023,0.029)$ \\
16 & $(34.49,44.16,55.00) \times(0.0017,0.0021,0.0026)$ & $(0.059,0.093,0.143)$ \\
17 & $(10.312,10.577,10.977) \times(0.0017,0.0021,0.0026)$ & $(0.017,0.022,0.028)$ \\
\hline
\end{tabular}


Table 6 The achieved amounts of $S_{k}$ s using Eq. (6) are presented in this table based on to show the degrees of possibility among two $S_{k}$ s by the index of a row to the index of a column

\begin{tabular}{|c|c|c|c|c|c|c|c|c|c|c|c|c|c|c|c|c|c|}
\hline$V\left(M_{1} \geq M_{2}\right)$ & $S_{1}$ & $S_{2}$ & $S_{3}$ & $S_{4}$ & $S_{5}$ & $S_{6}$ & $S_{7}$ & $S_{8}$ & $S_{9}$ & $S_{10}$ & $S_{11}$ & $S_{12}$ & $S_{13}$ & $S_{14}$ & $S_{15}$ & $S_{16}$ & $S_{17}$ \\
\hline$\rightarrow S_{1}$ & - & 1 & 1 & 1 & 0.24 & 1 & 1 & 1 & 0.92 & 0.92 & 1 & 1 & 1 & 1 & 1 & 1 & 1 \\
\hline$\rightarrow S_{2}$ & 1 & - & 1 & 1 & 0.24 & 1 & 1 & 1 & 0.92 & 0.92 & 1 & 1 & 1 & 1 & 1 & 1 & 1 \\
\hline$\rightarrow S_{3}$ & 0.64 & 0.64 & - & 1 & 0 & 1 & 1 & 1 & 0.54 & 0.54 & 1 & 1 & 1 & 1 & 1 & 0.65 & 1 \\
\hline$\rightarrow S_{4}$ & 0.49 & 0.49 & 0.85 & - & 0 & 1 & 1 & 1 & 0.39 & 0.39 & 1 & 1 & 1 & 1 & 1 & 0.50 & 1 \\
\hline$\rightarrow S_{5}$ & 1 & 1 & 1 & 1 & - & 1 & 1 & 1 & 1 & 1 & 1 & 1 & 1 & 1 & 1 & 1 & 1 \\
\hline$\rightarrow S_{6}$ & 0 & 0 & 0 & 0.18 & 0 & - & 1 & 1 & 0 & 0 & 1 & 1 & 1 & 1 & 1 & 0 & 1 \\
\hline$\rightarrow S_{7}$ & 0 & 0 & 0 & 0.18 & 0 & 1 & - & 1 & 0 & 0 & 1 & 1 & 1 & 1 & 1 & 0 & 1 \\
\hline$\rightarrow S_{8}$ & 0 & 0 & 0 & 0.18 & 0 & 1 & 1 & - & 0 & 0 & 1 & 1 & 1 & 1 & 1 & 0 & 1 \\
\hline$\rightarrow S_{9}$ & 1 & 1 & 1 & 1 & 0.27 & 1 & 1 & 1 & - & 1 & 1 & 1 & 1 & 1 & 1 & 1 & 1 \\
\hline$\rightarrow S_{10}$ & 1 & 1 & 1 & 1 & 0.27 & 1 & 1 & 1 & 1 & - & 1 & 1 & 1 & 1 & 1 & 1 & 1 \\
\hline$\rightarrow S_{11}$ & 0 & 0 & 0 & 0.16 & 0 & 1 & 1 & 1 & 0 & 0 & - & 1 & 1 & 1 & 1 & 0 & 1 \\
\hline$\rightarrow S_{12}$ & 0 & 0 & 0 & 0.16 & 0 & 1 & 1 & 1 & 0 & 0 & 1 & - & 1 & 1 & 1 & 0 & 1 \\
\hline$\rightarrow S_{13}$ & 0 & 0 & 0 & 0.16 & 0 & 1 & 1 & 1 & 0 & 0 & 1 & 1 & - & 1 & 1 & 0 & 1 \\
\hline$\rightarrow S_{14}$ & 0 & 0 & 0 & 0.18 & 0 & 1 & 1 & 1 & 0 & 0 & 1 & 1 & 1 & - & 1 & 0 & 1 \\
\hline$\rightarrow S_{15}$ & 0 & 0 & 0 & 0.06 & 0 & 0.92 & 0.92 & 0.92 & 0 & 0 & 0.92 & 0.92 & 0.92 & 0.92 & - & 0 & 1 \\
\hline$\rightarrow S_{16}$ & 0.98 & 0.98 & 1 & 1 & 0.21 & 1 & 1 & 1 & 0.89 & 0.89 & 1 & 1 & 1 & 1 & 1 & - & 1 \\
\hline$\rightarrow S_{17}$ & 0 & 0 & 0 & 0.03 & 0 & 0.83 & 0.83 & 0.83 & 0 & 0 & 0.83 & 0.83 & 0.83 & 0.83 & 0.91 & 0 & - \\
\hline
\end{tabular}

Table 7 Normalized weights of the alternatives with regard to MPI attribute

Table 8 Some of the normalized weights of attributes and normalized weights of alternatives for the pit area

\begin{tabular}{|c|c|c|}
\hline$V\left(M_{i} \geq M_{j}, \ldots, M_{k}\right)$ & $W^{\prime}\left(x_{i}\right)$ & $w_{i}$ \\
\hline$V\left(S_{1} \geq S_{2}, S_{3}, S_{4}, S_{5}, S_{6}, S_{7}, S_{8}, S_{9}, S_{10}, S_{11}, S_{12}, S_{13}, S_{14}, S_{15}, S_{16}, S_{17}\right)$ & 0.24 & 0.108 \\
\hline$V\left(S_{2} \geq S_{1}, S_{3}, S_{4}, S_{5}, S_{6}, S_{7}, S_{8}, S_{9}, S_{10}, S_{11}, S_{12}, S_{13}, S_{14}, S_{15}, S_{16}, S_{17}\right)$ & 0.24 & 0.108 \\
\hline$V\left(S_{3} \geq S_{1}, S_{2}, S_{4}, S_{5}, S_{6}, S_{7}, S_{8}, S_{9}, S_{10}, S_{11}, S_{12}, S_{13}, S_{14}, S_{15}, S_{16}, S_{17}\right)$ & 0 & 0 \\
\hline$V\left(S_{4} \geq S_{1}, S_{2}, S_{3}, S_{5}, S_{6}, S_{7}, S_{8}, S_{9}, S_{10}, S_{11}, S_{12}, S_{13}, S_{14}, S_{15}, S_{16}, S_{17}\right)$ & 0 & 0 \\
\hline$V\left(S_{5} \geq S_{1}, S_{2}, S_{3}, S_{4}, S_{6}, S_{7}, S_{8}, S_{9}, S_{10}, S_{11}, S_{12}, S_{13}, S_{14}, S_{15}, S_{16}, S_{17}\right)$ & 1 & 0.448 \\
\hline$V\left(S_{6} \geq S_{1}, S_{2}, S_{3}, S_{4}, S_{5}, S_{7}, S_{8}, S_{9}, S_{10}, S_{11}, S_{12}, S_{13}, S_{14}, S_{15}, S_{16}, S_{17}\right)$ & 0 & 0 \\
\hline$V\left(S_{7} \geq S_{1}, S_{2}, S_{3}, S_{4}, S_{5}, S_{6}, S_{8}, S_{9}, S_{10}, S_{11}, S_{12}, S_{13}, S_{14}, S_{15}, S_{16}, S_{17}\right)$ & 0 & 0 \\
\hline$V\left(S_{8} \geq S_{1}, S_{2}, S_{3}, S_{4}, S_{5}, S_{6}, S_{7}, S_{9}, S_{10}, S_{11}, S_{12}, S_{13}, S_{14}, S_{15}, S_{16}, S_{17}\right)$ & 0 & 0 \\
\hline$V\left(S_{9} \geq S_{1}, S_{2}, S_{3}, S_{4}, S_{5}, S_{6}, S_{7}, S_{8}, S_{10}, S_{11}, S_{12}, S_{13}, S_{14}, S_{15}, S_{16}, S_{17}\right)$ & 0.27 & 0.121 \\
\hline$V\left(S_{10} \geq S_{1}, S_{2}, S_{3}, S_{4}, S_{5}, S_{6}, S_{7}, S_{8}, S_{9}, S_{11}, S_{12}, S_{13}, S_{14}, S_{15}, S_{16}, S_{17}\right)$ & 0.27 & 0.121 \\
\hline$V\left(S_{11} \geq S_{1}, S_{2}, S_{3}, S_{4}, S_{5}, S_{6}, S_{7}, S_{8}, S_{9}, S_{10}, S_{12}, S_{13}, S_{14}, S_{15}, S_{16}, S_{17}\right)$ & 0 & 0 \\
\hline$V\left(S_{12} \geq S_{1}, S_{2}, S_{3}, S_{4}, S_{5}, S_{6}, S_{7}, S_{8}, S_{9}, S_{10}, S_{11}, S_{13}, S_{14}, S_{15}, S_{16}, S_{17}\right)$ & 0 & 0 \\
\hline$V\left(S_{13} \geq S_{1}, S_{2}, S_{3}, S_{4}, S_{5}, S_{6}, S_{7}, S_{8}, S_{9}, S_{10}, S_{11}, S_{12}, S_{14}, S_{15}, S_{16}, S_{17}\right)$ & 0 & 0 \\
\hline$V\left(S_{14} \geq S_{1}, S_{2}, S_{3}, S_{4}, S_{5}, S_{6}, S_{7}, S_{8}, S_{9}, S_{10}, S_{11}, S_{12}, S_{13}, S_{15}, S_{16}, S_{17}\right)$ & 0 & 0 \\
\hline$V\left(S_{15} \geq S_{1}, S_{2}, S_{3}, S_{4}, S_{5}, S_{6}, S_{7}, S_{8}, S_{9}, S_{10}, S_{11}, S_{12}, S_{13}, S_{14}, S_{16}, S_{17}\right)$ & 0 & 0 \\
\hline$V\left(S_{16} \geq S_{1}, S_{2}, S_{3}, S_{4}, S_{5}, S_{6}, S_{7}, S_{8}, S_{9}, S_{10}, S_{11}, S_{12}, S_{13}, S_{14}, S_{15}, S_{17}\right)$ & 0.21 & 0.094 \\
\hline$V\left(S_{17} \geq S_{1}, S_{2}, S_{3}, S_{4}, S_{5}, S_{6}, S_{7}, S_{8}, S_{9}, S_{10}, S_{11}, S_{12}, S_{13}, S_{14}, S_{15}, S_{16}\right)$ & 0 & 0 \\
\hline
\end{tabular}

\begin{tabular}{llllllllll}
\hline & Weight & A-AF & A-G & A-P & $\ldots$ & M-P & M-BTT & M-SRAC & M-MAT \\
\hline MMC & 0.127 & 0.367 & 0.391 & 0.092 & $\ldots$ & 0.268 & 0 & 0.136 & 0 \\
CAC & 0.114 & 0.336 & 0.347 & 0 & $\ldots$ & 0.462 & 0 & 0.351 & 0 \\
OPC & 0.111 & 0 & 0 & 0.197 & $\ldots$ & 0.026 & 0.047 & 0.040 & 0.009 \\
$\ldots$ & $\ldots$ & $\ldots$ & $\ldots$ & $\ldots$ & $\ldots$ & $\ldots$ & $\ldots$ & $\ldots$ & $\ldots$ \\
BW & 0 & 3.786 & 2.628 & 4.362 & $\ldots$ & 1.243 & 0 & 1.046 & 0 \\
BH & 0.039 & 0.102 & 0.102 & 0.230 & $\ldots$ & 0.086 & 0 & 0.080 & 0.165 \\
WS & 0.097 & 0.155 & 0.155 & 0.258 & $\ldots$ & 0.138 & 0 & 0.129 & 0 \\
\hline
\end{tabular}


Table 9 Relative importance coefficients of the alternatives of PMLUs for pit area of Sungun copper mine

\begin{tabular}{ll}
\hline Alternatives & $\begin{array}{l}\text { Relative } \\
\text { importance } \\
\text { coefficients }\end{array}$ \\
\hline A-AF & 0.732 \\
A-G & 0.769 \\
A-P & 2.479 \\
A-N & 0 \\
F-LP & 3.019 \\
F-W & 2.998 \\
F-SNF & 2.653 \\
L-L & 0 \\
L-A & 0 \\
L-AS & 0 \\
PB-WR & 0 \\
PB-GB & 0 \\
PB-L & 0 \\
M-P & 0 \\
M-BTT & 0 \\
M-SRAC & 0 \\
M-MAT & 0 \\
\hline
\end{tabular}

Table 10 Priorities of the PMLUs based on the achieved relative importance coefficients of the alternatives of PMLUs for pit area of Sungun copper mine

\begin{tabular}{lllllll}
\hline Alternatives & A-AF & A-G & A-P & F-LP & F-W & F-SNF \\
\hline Priorities & 6 & 5 & 4 & 1 & 2 & 3 \\
\hline
\end{tabular}

selected as the most appropriate alternative of PMLU for the pit area. Table 10 shows the obtained priorities of the PMLUs based on the achieved relative importance coefficients of the alternatives.

Figure 4 shows the diagram of declining relative importance coefficients of the alternatives for the pit area of Sungun copper mine. According to this diagram, forestry-lumber production (F-LP) has the biggest relative importance coefficient (3.019). Forestry-woodland (F-W) is the second alternative with the second relative importance coefficient (2.998) and forestry-shrubs and native forestation (F-SNF) is the third one with 2.653. Therefore, according to the diagram, forestry as the overall PMLU has the highest priority for pit area in this mine. Among three detailed PMLUs of forestry, F-LP has the highest priority so it is the OPMLU. F-W and F-SNF have the second and third priority, respectively; therefore, they are as the second and third choices for the pit area Sungun copper mine. It therefore can be concluded that according to the recognized OPMLU for the pit area in Sungun copper mine, reclamation costs of the pit area can be clarified. For clarification of the reclamation costs, costs will be estimated based on F-LP as the PMLU and the specifications of the mine site.

\section{Conclusion}

Selection of PMLU in open-pit mining plays a significant role with regard to clarification of mine closure and reclamation costs. It therefore affects the ultimate pit limit and subsequently the production planning. Mined land in openpit mining comprises of the following sections; pit(s), waste dump(s), tailing pond(s), roads, areas for on site facilities and free land zones which are not mined. Pit area due to its shape and depth, has effectual effects on the adjacent environment and also on selection of the optimum PMLU for the other sections of mined land. As there are several applicable alternatives, criteria, attributes and subattributes to define PMLU for pit area, multi-attribute decision-making methods are effective in this regard. Furthermore, the nature of the effective parameters for defining the OPMLU includes incremental changes without definite limits same as Fuzzy numbers changes. Thus, pairwise comparisons and judgments through Fuzzy numbers have an appropriate consistency and reliability rate in the
Fig. 4 Diagram of declining relative importance coefficients of the alternatives for the pit area

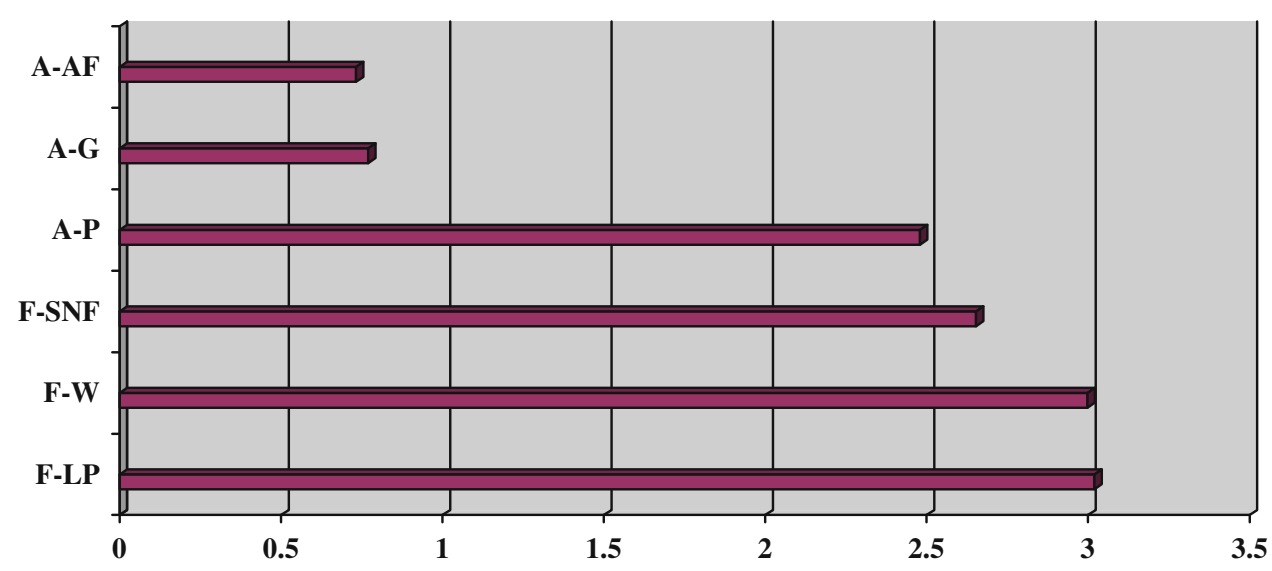


obtained results. Therefore, Fuzzy analytical hierarchy processing was selected as the technique which can produce more reliable results than the other techniques. Accordingly, a model was developed to identify the OPMLU for pit area in open-pit mining. The developed model consists of 17 applicable PMLU alternatives, five relevant effective criteria, 96 attributes and sub-attributes for defining the OPMLU for pit area. The developed model was implemented in Sungun copper mine in northwest of Iran as the case study. According to the obtained results from the case study, F-LP has the greatest relative importance coefficient 3.019, F-W is the second choice with relative importance coefficient 2.998 and F-NSF is the third one with relative importance coefficient 2.653 . Therefore, forestry is as overall PMLU with the highest priority for the pit area in this mine. Among three detailed PMLUs of forestry, F-LP is the OPMLU with the highest priority. F-W and F-SNF are the second and third choices for the pit area in Sungun copper mine. Due to the recognized OPMLU (F-LP) for pit area in Sungun copper mine, reclamation costs can be clarified in this project.

Acknowledgments The authors also wish to extend their sincere gratitude to all who assisted in promoting the present work.

\section{Appendix}

See Table 11.

Table 11 The acronyms used through the whole paper

\begin{tabular}{lll}
\hline No. & Acronym & Description \\
\hline 1 & A-AF & Agriculture-arable farmland \\
2 & AEPG & Australian Environment Protection Agency \\
3 & AG & Alberta Government \\
4 & A-G & Agriculture-garden \\
5 & AGP & Acid generation potential \\
6 & AHP & Analytical hierarchy processing \\
7 & AM & Air moisture \\
8 & A-N & Agriculture-nursery \\
9 & A-P & Agriculture-pasture \\
10 & ARC & Accessibility or road condition \\
11 & Area. & Pit area \\
12 & ARPE & Authority of reclamation project execution \\
13 & BAOC & Back to original contour \\
14 & BEP & Break even point \\
15 & BEV & Block economic values \\
16 & BH & Benches height \\
17 & BLM & Bureau of Land Management \\
18 & BPP & Budget providing potential \\
19 & BSlop. & Benches slope \\
20 & BW & Benches width \\
\hline & &
\end{tabular}

Table 11 continued

\begin{tabular}{|c|c|c|}
\hline No. & Acronym & Description \\
\hline 21 & CAC & Capital costs \\
\hline 22 & Clim. & Climate \\
\hline 23 & CLR & Consistency with local requirements \\
\hline 24 & CLUS & Current land use in surrounding area \\
\hline 25 & $\begin{array}{l}\text { CO/ } \\
\text { NRMLRD }\end{array}$ & $\begin{array}{l}\text { Colorado Department of Natural Resources, } \\
\text { Mined Land Reclamation Division }\end{array}$ \\
\hline 26 & $\mathrm{CR}$ & Contamination rate \\
\hline 27 & Cult. & Cultural \\
\hline 28 & Depth. & Pit depth \\
\hline 29 & Drain. & Drainage \\
\hline 30 & DSS & Distance from special services \\
\hline 31 & EA & Ecological acceptability \\
\hline 32 & EACS & Easy accessibility in cold seasons \\
\hline 33 & $\mathrm{EC}$ & Environmental contaminations \\
\hline 34 & EEP & Extreme event potential \\
\hline 35 & EIA & Environmental impact assessment \\
\hline 36 & EITA & Effects on immigration to the area \\
\hline 37 & Elev. & Overall regional elevation \\
\hline 38 & EMEA & Executive managing experiences availability \\
\hline 39 & EO & Employment opportunity \\
\hline 40 & EPPCA & $\begin{array}{l}\text { Environmental Protection and Pollution Control } \\
\text { Act }\end{array}$ \\
\hline 41 & FA & Facilities accessibility \\
\hline 42 & FAHP & Fuzzy analytical hierarchy processing \\
\hline 43 & FFD & Frost-free days \\
\hline 44 & FLPMA & Federal Land Policy and Management Act \\
\hline 45 & F-LP & Forestry-lumber production \\
\hline 46 & FPT & Frequency of passing through mine site \\
\hline 47 & F-SNF & Forestry—shrubs and native forestation \\
\hline 48 & $\mathrm{~F}-\mathrm{W}$ & Forestry—woodland \\
\hline 49 & Geog. & Geographical \\
\hline 50 & GP & Government policy \\
\hline 51 & GS & Geographical situation \\
\hline 52 & HRES & High rate earthquake statistics \\
\hline 53 & HSG & Hydrology of surface and groundwater \\
\hline 54 & ICME & $\begin{array}{l}\text { International Council on Metals and the } \\
\text { Environment }\end{array}$ \\
\hline 55 & IGI & Increase in governmental incomes \\
\hline 56 & IIL & Increase in income of local community \\
\hline 57 & INAC & Indian and Northern Affairs Canada \\
\hline 58 & Incom. & Income \\
\hline 59 & IRPT & $\begin{array}{l}\text { Increase in regional public skills and technical } \\
\text { knowledge }\end{array}$ \\
\hline 60 & IRR & Internal rate of return \\
\hline 61 & L-A & Lake-aquaculture \\
\hline 62 & L-AS & Lake-aquatic sports \\
\hline 63 & $\mathrm{~L}-\mathrm{L}$ & Lake-lagoon \\
\hline 64 & LNT & Location towards nearest town \\
\hline 65 & LO & Land ownership \\
\hline
\end{tabular}


Table 11 continued

\begin{tabular}{|c|c|c|}
\hline No. & Acronym & Description \\
\hline 66 & LQ & Landscape quality \\
\hline 67 & MA & Market availability \\
\hline 68 & MADM & Multi-attribute decision making \\
\hline 69 & M-BTT & Miscellaneous_-blasting techniques training \\
\hline 70 & MCP & Mining company policy \\
\hline 71 & M-MAT & Miscellaneous_-military activity training \\
\hline 72 & MMC & Maintenance and monitoring costs \\
\hline 73 & M-P & Miscellaneous-Park \\
\hline 74 & MPI & Mining project income \\
\hline 75 & M-SRAC & Miscellaneous_-ski and rock artificial climbing \\
\hline 76 & NPV & Net present value \\
\hline 77 & NSW & Need to specialist workforces \\
\hline 78 & NWT & $\begin{array}{l}\text { Mining reclamation regime in the northwest } \\
\text { territories }\end{array}$ \\
\hline 79 & OFB & Outlook of future businesses \\
\hline 80 & OMNE & Organic material and nutrient elements \\
\hline 81 & $\mathrm{OPC}$ & Operational costs \\
\hline 82 & OPMLU & Optimum post-mining land use \\
\hline 83 & PB-GB & Pit backfilling—garbage burying \\
\hline 84 & PB-L & Pit backfilling_landfill \\
\hline 85 & PB-WR & Pit backfilling-water reservoir \\
\hline 86 & PCRE & Positive changes in real estate value \\
\hline 87 & PCLQ & Positive changes in livelihood quality \\
\hline 90 & PIA & Potential of investment absorption \\
\hline 91 & Pit G. & Pit geometry \\
\hline 92 & PMA & Prosperity in the mine area \\
\hline 93 & PMLU & Post-mining land use \\
\hline 94 & PMP & Proximity of mine site to population centers \\
\hline 95 & PP & Production planning \\
\hline 96 & Prec. & Precipitation \\
\hline 97 & PSlop. & Pit slope \\
\hline 98 & PWS & Proximity to water supply \\
\hline 99 & RCEA & Regional common economical activities \\
\hline 100 & RCTSMR & $\begin{array}{l}\text { Railroad Commission of Texas Surface Mining } \\
\text { and Reclamation Division }\end{array}$ \\
\hline 101 & RECC & Regional economical condition coordination \\
\hline 102 & RECS & Regional ethnic custom specifications \\
\hline 103 & RES & Regional exposure to sunrise \\
\hline 104 & RFF & Regional flora and fauna \\
\hline 105 & RFP & Regional flood potential \\
\hline 106 & $\mathrm{RMC}$ & Regional moral customs \\
\hline 107 & RMEA & Required machines and equipment availability \\
\hline 108 & RO & Regional opponents \\
\hline 109 & RPC & Regional political condition \\
\hline 110 & RPI & $\begin{array}{l}\text { Regional potential for implementation the new } \\
\text { land use }\end{array}$ \\
\hline 111 & RPL & Regional pezometeric level \\
\hline 112 & RPMF & Reusing potential of mine facilities \\
\hline 113 & RSA & Regional social activities \\
\hline
\end{tabular}

Table 11 continued

\begin{tabular}{lll}
\hline No. & Acronym & Description \\
\hline 114 & RSC & Regional safety condition \\
115 & RTA & Reclamation technique availability \\
116 & Salin. & Salinity rate \\
117 & SCA & Social and cultural condition of adjacent areas \\
118 & SER & Surface evaporation rate \\
119 & SG & Structural geology \\
120 & Slop. & Overall regional slope \\
121 & SMCRA & Surface Mining Control and Reclamation Act \\
122 & Soil-P.S. & Soil physical specifications \\
123 & SPE & Serving the public education \\
124 & SSML & Shape and size of mined land \\
125 & SR & Surface relief \\
126 & TA & Tourism attractions \\
127 & Temp. & Regional average temperature \\
128 & Topo. & Topography \\
129 & UNDDSMS & United Nations Department of Development \\
& & Support and Management Services \\
130 & UNEP/IEO & United Nations Environment Program / Industry \\
& & and Environment Program Activity Center \\
131 & UNESCAP & United Nations Economic and Social \\
& & Commission for Asia and the Pacific \\
132 & UNRFNRE & United Nations Revolving Fund for Natural \\
133 & UPL & Resources Exploration \\
134 & VC & Vltimate pit limit \\
135 & VCD & Very cold days \\
136 & VHD & Very hot days \\
137 & Vol. & Pit volume \\
138 & WS & Wall stability \\
& & Wind velocity \\
& Zoning by-laws \\
\hline
\end{tabular}

\section{References}

ABAG-Association of Bay Area Governments (1995) Manual and standards for erosion and sediment control measures, May 1995. California, USA

Abaza H (1993) Environmental economics and natural resource management in developing countries. appraisal methodology for sustainable development projects. World Bank, Washington, DC, pp 17-71

AEPG-Australian Environment Protection Agency (1995) Best practice environmental management in mining, rehabilitation and revegetation. Department of Environment, Commonwealth of Australia, Canberra

AG-Alberta Government (2007) A guide to: reclamation criteria for Wellsites and associated facilities-forested lands in the green area. Alberta Sustainable Resource Development Lands Division, USA, pp 4-20

Alexander MJ (1998) The effectiveness of small-scale irrigated agriculture in the reclamation of mine land soils on the Jos Plateau of Nigeria. Land Degrad Dev 7(1):77-85 
Altuzarra A, Moreno Jimenez JM, Salvador M (2004) Searching for consensus in AHP-Group decision making, A Bayesian Perspective, Gobierno electronic, Toma de decisiones complejas basadas en Internet: e-democracia y e-cognocracia, pp 43-52

BAOC_-Back to Original Contour (1977) Surface mining control and reclamation act (SMCRA), U.S. Department of Interior, Office of Surface Mining Reclamation and Enforcement (OSM, Edited 1988)

Bandopadhyay S, Chattopadhyay A (1986) Selection of post mining uses of land via Fuzzy algorithm, In: Ramani RV (ed) Proceedings of the 19th international symposium on the application of computers in mine planning (APCOM), SME/AIME, 65-66, pp 321-332

Barth RC, Severson RC, Weiler G (1987) Reclaiming mine soils and overburden in the western United States. In: Williams RD, Schuman GE (eds) Analytic parameters and procedures. Soil Conservation Society of America, Ankeny, pp 135-153

Bascetin A (2007) A decision support system using analytical hierarchy process (AHP) for the optimal environmental reclamation of an open-pit mine. Environ Geol 52(4):663-672

BLM-Bureau of Land Management (1992) Solid minerals reclamation handbook (BLM Manual Handbook H-3042-1), US Department of the Interior, USA, pp 1-136

Boer B (1994) International strategies for implementing sustainable development: the roles of national state and local governments in translating grand strategy into action. Willamette Law Rev 1994:9-30

Bojadziev G, Bojadziev M (1998) Fuzzy sets and Fuzzy logic applications. World Scientific, Singapore

Bruntland G (1987) Our common future: The World Commission on Environment and Development. Oxford University, Oxford

Buckley JJ (1985) Fuzzy hierarchical analysis. Fuzzy Sets Syst 17:233-247

Burger JA (2004) Restoring forests on mined land in the Appalachians: results and outcomes of a 20-year research program In: Proceedings of a joint conference of American Society of Mining and Reclamation, 21st annual national conference, and 25th West Virginia surface mine drainage task force symposium, Morgantown, West Virginia, pp 18-22

Buyukozkan G, Kahraman C, Ruan D (2004) A Fuzzy multi-criterial decision approach for software development strategy selection. Int J Gen Syst 33(2-3):259-280

Cairns J (1972) Ecological considerations in reclaiming surface mined lands. Miner Environ 1(3):83-89

Cao X (2007) Regulating mine land reclamation in developing countries: the case of China. Land Use Policy 24:472-483

Chen H, Zheng C, Zhu Y (1999) Phosphorus: a limiting factor for restoration of soil fertility in a newly reclaimed coal mined site in Xuzhou, China. Land Degrad Dev 9(2):115-121

Cheng CH (1996) Evaluating naval tactical missile systems by Fuzzy AHP based on the grade value of membership function. Eur $\mathrm{J}$ Oper Res 96:343-350

Cheng JH, Tang CH (2009) An application of fuzzy Delphi and fuzzy AHP for multi-criteria evaluation on bicycle industry supply chains. Wseas Transact Syst Control 4(1):21-34

CO/NRMLRD - Colorado Department of Natural Resources-Mined Land Reclamation Division (1992) Guidelines for Cyanide Leaching Projects

EPPCA-Environmental Protection and Pollution Control Act (1990). Environmental Council of Zambia (ECZ), Act No. 12

Erensal YC, Oncan T, Demircan ML (2006) Determining key capabilities in technology management using Fuzzy analytic hierarchy process: a case study of Turkey. Inf Sci 176:2755-2770

Ertugrul I, Karakasoglu N (2009) Performance evaluation of Turkish cement firms with Fuzzy analytic hierarchy process and TOPSIS methods. Expert Syst Appl 36(1):702-715
FLPMA-Federal Land Policy and Management Act (1976) The Federal Land Policy and Management Act, as amended, U.S. Department of the Interior, Bureau of Land Management and Office of the Solicitor (editors, 2001) Office of Public Affairs, Washington, D.C., pp 69-78

Herrera F, Herrera VE (2000) Linguistic decision analysis: steps for solving decision problems under linguistic information. Fuzzy Sets Syst 115:67-82

Higgs TW (1992) Technical guide for the environmental management of cyanide in mining. British Columbia Technical and Research Committee on Reclamation, Cyanide Sub-Committee, prepared by T.W. Higgs Associates Ltd in association with EVS Consultants Ltd, ASL Laboratories Ltd, and Gormely Process Engineering

Hill C (2003) Deloro Mine site clean-up mine area rehabilitation alternatives final report. Prepared for Ontario Ministry of the Environment, pp 23-25

Huang LC, Wu RYH (2005) Applying Fuzzy analytic hierarchy process in the managerial talent assessment model - an empirical study in Taiwan's semiconductor industry. Int J Technol Manage 30(1/2):105-130

ICME (1991a) Environmental Policy Chapter. Int Council Metals Environ 1(1):4-5

ICME (1991b) Development in Zambia. Int Council Metals Environ 2(1):11-12

INAC-Indian and Northern Affairs Canada (2002a) Mine reclamation guidelines for the northwest Territories and Nunavut, Draft

INAC-Indian and Northern Affairs Canada (2002b) Mine site reclamation policy for the northwest Territories

Isabell MW (2004) Forestry: a practical land use for surface mining? In: Proceedings of a joint conference of American Society of Mining and Reclamation, 21st Annual National Conference, and 25th West Virginia Surface Mine Drainage Task Force Symposium, Morgantown, West Virginia, pp 46-54

Joerin F, Theriault M, Musy A (2001) Using GIS and outranking multi criteria analysis for land-use suitability assessment. Int $\mathbf{J}$ Geogr Inf Sci 15(2):153-174

Knabe W (1964) Methods and results of strip-mining reclamation in Germany. Ohio J Sci 64:75-105

Liang WY (2003) The analytic hierarchy process in project evaluation: an R\&D case study in Taiwan. Benchmarking: Benchmark Int J 10(5):445-456

Limpitlaw D (2001) GIS-based assessment for environmental management in the Zambian Copperbelt, In: Proceedings of the chamber of mines of SA conference on environmentally responsible mining, Johannesburg, September 26-28, vol. 2, pp 5A18-5A27

Limpitlaw D (2003) An assessment of mining impacts on the environment in the Zambian Copperbelt, $\mathrm{PhD}$ Thesis, submitted to the Faculty of Engineering, University of the Witwatersrand, pp 285-295

Mcefish JM (1996) Hard rock mining: state approaches to environmental protection. Environmental Law Center, Washington DC

Mchaina DM (2001) Environmental planning considerations for the decommissioning, closure and reclamation of a mine site. Int $\mathrm{J}$ Surf Min Reclam Environ 15:163-176

Mikhailov L, Tsvetinov P (2004) Evaluation of services using a Fuzzy analytic hierarchy process. Applied Soft Computing 5:23-33

Mu Y (2006) Developing a Suitability Index for Residential Land Use: A case study in Dianchi Drainage Area. MSc Thesis, Waterloo, Ontario

Mudder T, Botz M (2001) A guide to cyanide mining. Environ Manag 9:8-12

Naghadehi MZ, Mikaei R, Ataei M (2009) The application of Fuzzy analytic hierarchy process (FAHP) approach to selection of optimum underground mining method for Jajarm Bauxite Mine. Iran, Expert Syst Appl 36:8218-8226 
Northwest Territories Water Board (1990) Guidelines for Abandonment and Restoration Planning for Mines in the Northwest Territories

NWT (2005) The mining reclamation regime in the Northwest Territories: a comparison with selected Canadian and U.S. Jurisdictions, Mining Reclamation in the NWT

Osanloo M (2001) Mine reclamation (in Persian). 1, Amir Kabir University of Technology Press, Iran, pp 10-20

Osanloo M, Akbari AD, Hamidian H (2006) Selecting post mining land use through analytical hierarchy processing method: case study in Sungun copper open pit mine of Iran. In: Proceedings of 15th international symposium of MPES, Torino, Italy, pp 1-12

Ramani RV, Sweigard RJ, Clar ML (1990) Reclamation planning, Chap. 6.6.2, Surface mining, 2nd edn, SME, Littleton, pp 750-769

Rashidinejad F (2004a) Sungun copper project environmental impact assessment. In: Proceedings of the 8th international symposium on environmental issues and waste management in energy and mineral production (SWEMP), Antalya, Turkey, 133-138

Rashidinejad F (2004b) Tailings disposal options study at Sungun copper mine. In: Proceedings of the 13th international symposium on mine planning and equipment selection (MPES), Held in Wroclaw, Poland, pp 857-862

Rashidinejad F, Osanloo M, Rezai B (2008) An environmental oriented model for optimum cut-off grades in open pit mining projects to minimize acid mine drainage. Int J Environ Sci Tech 5(2):183-194

RCTSMR-Railroad Commission of Texas Surface Mining and Reclamation Division (2002) Texas abandoned mine land reclamation projects. Texas Abandoned Mine Land Reclam $11: 10-25$

Saaty TL (1977) A scaling method for priorities in hierarchical structures. J Math Psychol 15:234-281

Saaty TL (1980) The Analytical Hierarchy Process. McGraw Hill Company, New York, (Reprint in Int J Services Sci (2008) $1(1): 83-98)$

Saaty TL (1990) How to make a decision: the analytic hierarchy process. Eur J Oper Res 48:9-26

Safari M, Khalokakaei R, Ataei M, Karamozian M (2010) Using fuzzy TOPSIS method for mineral processing plant site selection Case study: Sangan iron ore mine (phase 2), Arab J Geosci (Published online: 02 December 2010)

SMCRA-Surface Mining Control and Reclamation Act (1977) Public Law 95-87, Passed August 3, and all revisions through December 31: 251-263

Soltanmohammadi H, Osanloo M, Aghajani A (2008) Developing a fifty-attribute framework for mined land suitability analysis using AHP-TOPSIS approach. In: proceedings of post-mining symposium, Nancy, France, pp 1-12

Soltanmohammadi H, Osanloo M, Rezaee B, Aghajani A (2008b) Achieving to some outranking relationships between postmining land uses through mined land suitability analysis. Int $\mathbf{J}$ Environ Sci Tech 5(4):535-546

Soltanmohammadi H, Osanloo M, Aghajani A (2009a) Deriving preference order of post-mining land-uses through MLSA framework: application of an outranking technique. Environ Geol 58:877-888

Soltanmohammadi H, Osanloo M, Aghajani A (2009) An analytical approach with a reliable logic and a ranking policy for postmining land-use determination, Elsevier Ltd., Science Direct website, Available online 9 June

Song W, Yang L (2006) Research on the Principle and Methodology of Open Pit Dumping Area Ecological Restoration and
Rebuilding, Proceedings of Promoting Land Administration and Good Governance 5th FIG Regional Conference Accra, Ghana, March 8-11, 1-5

Stejskal J (2004) Czech Republic: Towards the Reclamation of Derelict Land, Report, Institute for Spatial Development (ÚÚR), Brno, pp 18-22

Uberman R, Ostrêga A (2005) Applying the analytic hierarchy process in the revitalization of post-mining regions. ISAHP, Honolulu

UNDDSMS-United Nations Department of Development Support and Management Services and United Nations Environment Program (1994) Environmental Guidelines for Mining Operations, New York

UNEP/IEO (1991) Environmental Aspects of Selected Non-ferrous Metals $(\mathrm{Cu}, \mathrm{Ni}, \mathrm{Pb}, \mathrm{Zn}, \mathrm{Au})$ Mining - A Technical Guide, UNEP, Industry and Environment Program Activity Center, Paris

UNESCAP-United Nations Economic and Social Commission for Asia and the Pacific (1992) Environmental Impact Assessment Guidelines for Mining Development, ESCAP - Environmental and Development Services, Bangkok and Thailand, ST0ESCA P01038

United Nations (1992) Mining and the Environment, The Berlin Guidelines. A study based on the International Round Table in June 1991, Mining Journal Books, London

United Nations (1993) International Workshop on Environmental Management at Mining Sites In Developing Countries, held on 6-10 December, at Konkola, Zambia, United Nations Department of Development Support and Management Services and United Nations Environment Program, New York

United Nations-Department of Public Information (1992) Earth Summit: Agenda 21, The United Nations Program of Action from Rio

UNRFNRE-United Nations Revolving Fund for Natural Resources Exploration (1993) Environmental Protection Guidelines, New York, p 10017

Vogel WG (1981) A guide for revegetating coal minesoils in the eastern United States, General Technical Report. NE-68. Forest Service, U.S. Department of Agriculture, Broomall

Warren L (2004) Uncertainty in the analytic hierarchy process, Technical Report DSTO-TN-0597, Australian Government Department of Defence. Command and Control, Division Information Sciences Laboratory

White W, Lapakko K, Cox R (1999) Static-test methods most commonly used to predict acid-mine drainage: practical guidelines and interpretation. In: Plumlee GS, Logsdon MS (eds), The environmental geochemistry of mineral deposits. Part A: Processes, techniques and health issues, Society of Economic Geologists, Littleton Reviews in economic geology, vol. 6A: 325-338

Whittle J (1988) Beyond optimization in open pit mining, In: Canadian Conference on Computer Application in the Mineral Industries Proceedings, Balkema, Rotterdam, pp 331-337

Whittle J (1989) The facts and fallacies of open pit optimization, Whittle Programming Pty Ltd., North Balwyn, 1-7

Whittle J (1990) Open pit optimization, surface mining. 2nd edn. Society for Mining Metallurgy and Exploration Inc., USA, pp 470-475

World Bank, UNEP, UNCTAD, ICME (1994) Development, environment and mining, enhancing the contribution of the mineral industry to sustainable development, Washington, DC., June 1-3

Zadeh L (1965) Fuzzy sets. Information control 8:338-353 